CZASOPISMO INŻYNIERII LĄDOWEJ, ŚRODOWISKA I ARCHITEKTURY JOURNAL OF CIVIL ENGINEERING, ENVIRONMENT AND ARCHITECTURE JCEEA, t. XXXIII, z. 63 (2/I/16), kwiecień-czerwiec 2016, s. 171-178

\author{
Michał MUSIAt ${ }^{1}$ \\ Marcin KACZMARZYK ${ }^{2}$
}

\title{
THERMAL PROPERTIES OF TRANSPARENT BARRIER MODIFIED WITH ORGANIC PCMS
}

\begin{abstract}
Renewable energy sources are increasingly often applied in civil engineering as a mean to reduce buildings energy demand for heating. One of the ways to reduce HVAC energy demand is to limit heat transfer and excessive solar gain through building's glazed barriers. Preliminary results of the research conducted on organic PCM-modified transparent barrier are presented in this paper.

Multiple publications concerning PCMs application in structural materials have recently appeared. Most of them are focused on modification of structure of nontransparent sections of buildings' envelope. Augmenting a glazed barrier with PCMs increases its heat capacity and thermal resistance. The most important feature of the assembly is the thermal buffer, a product of PCM's considerable value of specific latent heat.

Research were conducted on a triple-pane transparent rectangular barrier, that constituted one of the faces of cubic chamber. Internal volume of the chamber was $1 \mathrm{~m}^{3}$. The applied PCM was a mixture of saturated and non-saturated hydrocarbons. The described assembly was subjected to temperature and radiation that occur in Poland during winter. Glazing temperature, melted/total PCM ratio were measured, as well as energy demand for keeping internal temperature at constant level. Measurements were made in steady states, for various PCM layer thickness. The influence of the modification on energy demand was determined, along with the most effective and rational thickness of PCM layer to be applied.

Conducted research enabled to develop a basis for further investigation of PCMs application in civil engineering.
\end{abstract}

Keywords: phase change materials, modified transparent barriers, latent heat, thermal insulation

\section{Introduction}

Reduction of energy consumption for heating and cooling building's interior, while maintaining thermal comfort of it's users is an important issue for

\footnotetext{
${ }^{1}$ Corresponding author: Michał Musiał, Rzeszow University of Technology, 35-959 Rzeszow, al. Powstańców Warszawy 12, tel. 178651005, email: mmusial@prz.edu.pl

${ }^{2}$ Marcin Kaczmarzyk, Rzeszow University of Technology, 35-959 Rzeszow, al. Powstańców Warszawy 12, tel. 178651005, email: kaczmar@prz.edu.pl
} 
modern engineering. One of the solutions to the problem is to increase thermal inertia of building's envelope. In order to accomplish it without significant increase of thickness and mass of the envelope, phase change materials (PCMs) are to be used.

PCMs are substances of high specific latent heat $(100-280 \mathrm{~kJ} / \mathrm{kg})$ for liquid-solid phase transition. PCMs used in civil engineering may be either organic or inorganic compounds. Among organic PCMs one can name saturated hydrocarbons (Alkanes), Esters, alcohols, Fatty acids, as well as some ethylene glycol's polymers. Inorganic PCMs applied in building engineering are represented by hydrated salts of alkali metals and of alkaline earth metals, and their eutectic systems[6].

A significant increase of interest with PCMs' applications in building industry as well as in the field of scientific research is to be observed in last several years. There are numerous research concerning PCMs applications in building barriers made of opaque materials[3], [5].

It is to be noticed, that an important solution for building engineering is combining PCMs with transparent barriers, in order to temporary store heat from solar radiation [1], [2], [4], [8]. This solution increases heat capacity of whole assembly, making it less susceptible for short-term temperature changes, thus improves it's efficiency in comparison with traditional solutions. Undoubdtly, the major disadvantage of described solution is it's significantly reduced transmittance [4], a result of incorporating a layer of PCM with insulated glazing, that makes the whole translucent, rather than transparent.

Typical applications of PCMs in transparent barriers were described in [4], where double paned window was being equipped with various glass units, filled with propylene glycol.

Obtained results were compared with those from numerical model, and both confirms, that radiative heat flow in infrared and ultraviolet was significantly reduced, while achieving satisfying transmittance in visible light spectrum.

However, this analysis refers to the situation of frequent overheating of a building, so it does not match polish, temperate climate conditions.

Another opportunity to use PCMs in direct gain windows is to fill lathes of window shutter with the substance. Actions of those shutters are controlled by special devices, that monitor indoor and outdoor temperature, as well as incident solar radiation. That solution enables to intercept and store excessive heat during the day and utilise it during the night.

Research conducted in Karlsruhe and Kassel [8] (Germany) proofed the solution to be most efficient during the winter, when applied to light-envelope building, increases its thermal inertia and improves thermal comfort of its occupants.

In the summer, minor increase of average indoor temperature was noticed, although daily temperature variations were reduced. In addition, using those shutters resulted in decrease of air conditioning units' peak energy consumption. 
Phase change materials are increasingly often used as heat storages in renewable energy systems, they also accumulate heat in direct gain systems.

The most common applications of PCMs are listed below:

- absorption of excessive heat from photovoltaic panels, that prevents to decrease PV cells' efficiency due to overheating [5],

- augmenting hot water storage tanks, often supplied by solar thermal collectors,

- modifications of Trombe walls.

\section{Description of the research workstation}

Research were conducted in simulated conditions of heating season in temperate climate (Poland). Workstation was assembled as cubic framework chamber of internal dimensions $1 \times 1 \times 1 \mathrm{~m}$ and interior volume $1 \mathrm{~m}^{3}$.

A triple-pane window constituted one of chamber's faces, the remaining five were made of thermal insulating material. The glazing $(0,8 \times 0,8 \mathrm{~m})$ was subjected to irradiance of $750 \mathrm{~W} / \mathrm{m}^{2}$ for six hours a day. Inside the chamber, a heat source was installed, along with a temperature control system and an energy meter. The internal temperature was kept constant $22^{\circ} \mathrm{C}+-0,5^{\circ} \mathrm{C}$. The chamber was fit inside conditioned compartment, that kept it's internal, constant temperature $0^{\circ} \mathrm{C}+-0,5^{\circ} \mathrm{C}$.

Photographs and detailed schematics of the workstation are presented in Fig. 1-3.

The glass unit was modified with so called component, that contained nontoxic organic compounds of melting point $38-42^{\circ} \mathrm{C}$ and specific latent heat $130 \mathrm{~kJ} / \mathrm{kg}$. The casing of the component was a sheet of clear, cellular polycarbonate. The casing is to be seen in Fig 4-5.

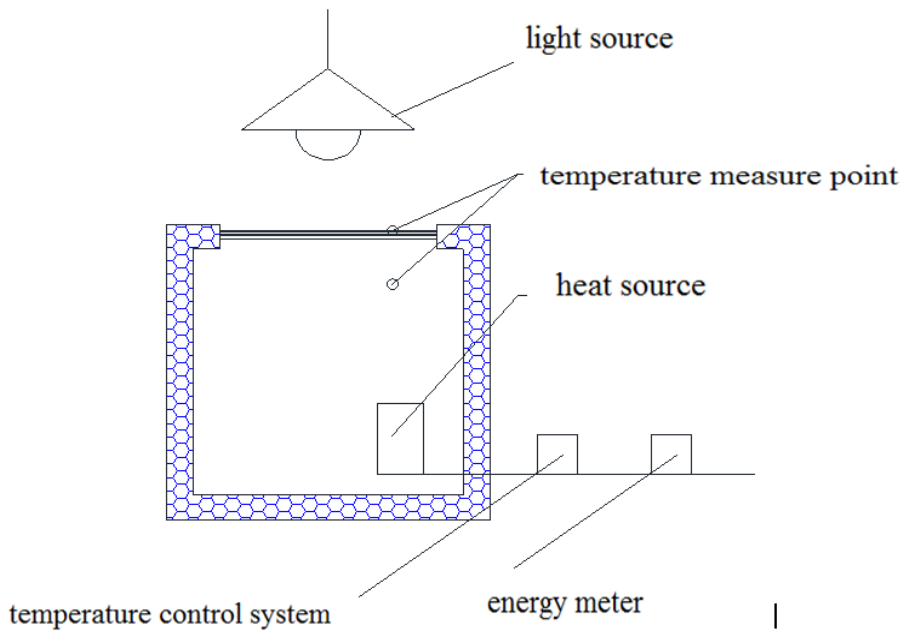

Fig. 1. Workstation's schematics

Rys. 1. Schemat stanowiska badawczego 


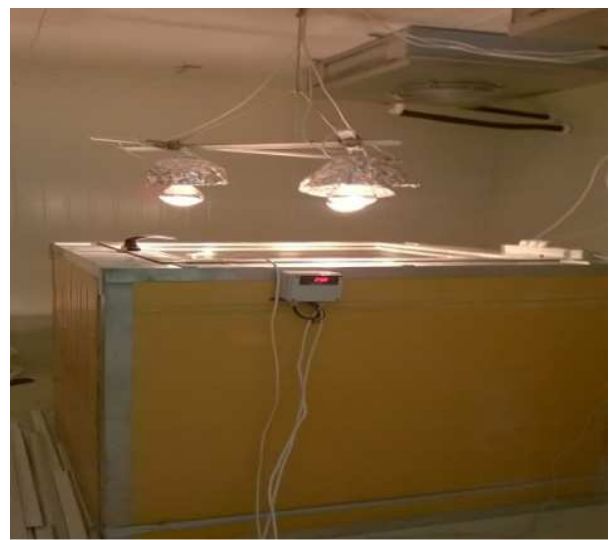

Fig. 2. A photo of the workstation

Rys. 2. Zdjęcie stanowiska badawczego

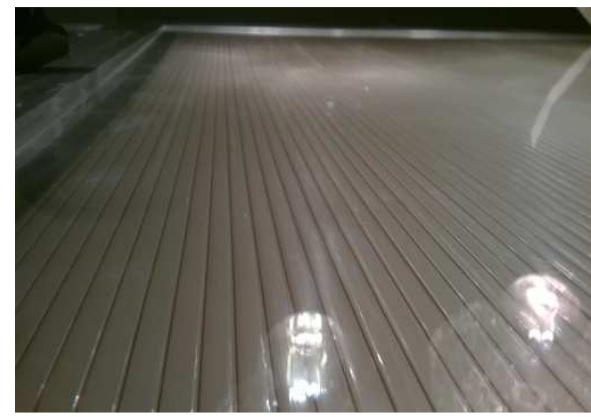

Fig. 4. Clear sheet of cellular polycarbonate Rys. 4. Zdjęcie płyty poliwęglanu komorowego z PCM

\section{Methodology}

The main subject of the research was the transparent barrier, one of the faces of described research chamber.

It was being modified by component with PCM, as follows:

- unmodified glass unit,

- glass unit with $5 \mathrm{~mm}$ component mounted on external surface,

- glass unit with $5 \mathrm{~mm}$ component mounted on internal surface.

For those variants, thermal response of the glazing and of chamber's interior were measured, as well as total energy consumption for air conditioning. In order to ensure that obtained results are reliable and repetitive, every variant of 
experiment was conducted ten times, 24 hours each. The results presented below are average of all, ten experiments.

\section{Results}

The charts below (Fig. 6-8) illustrate average energy consumption, by chamber's heating system. Energy consumption was measured using electronic energy meter.
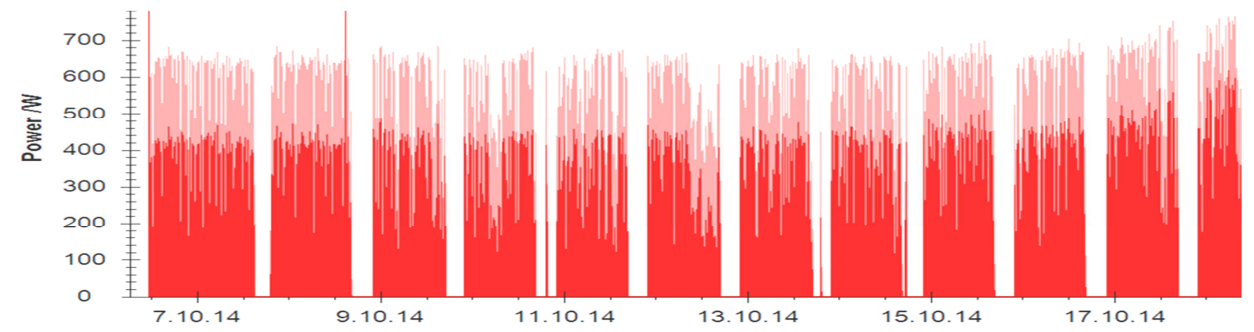

Fig. 6. Energy consumption in a chamber with unmodified glass unit

Rys. 6. Wykres zużycia energii dla komory z konwencjonalnym przeszkleniem

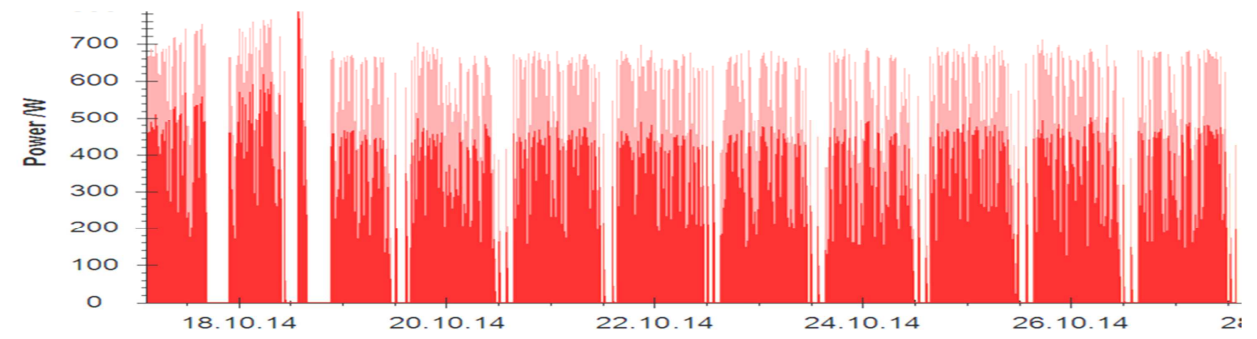

Fig. 7. Energy consumption in a chamber with glass unit modified with component mounted on external surface

Rys. 7. Wykres zużycia energii przy umieszczeniu kompozytu od strony zewnętrznej przeszklenia

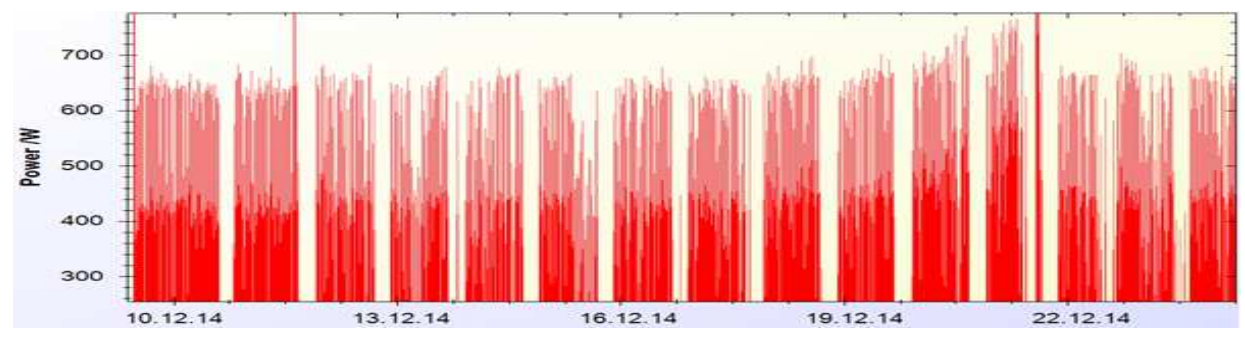

Fig. 8 Energy consumption in a chamber with glass unit modified with component mounted on internal surface

Rys. 8. Wykres zużycia energii przy umieszczeniu kompozytu od strony wewnętrznej przeszklenia 
Figures 9-10 compare temperature variations of the glazing and of chamber's interior in case of modified and unmodified glazing.

Differences in transmittance of solid and melted portions of PCM in a component are presented in Fig.11.

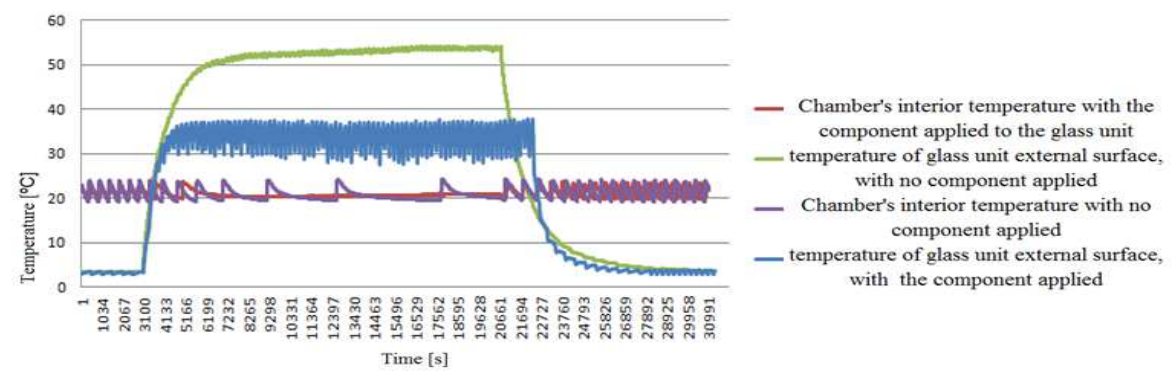

Fig. 9. Temperatures of the glazing and of internal air for unmodified glazing and internally modified glazing

Rys. 9. Wykres zestawiający temperatury przeszklenia i powietrza wewnątrz komory dla przeszklenia z PCM od wewnętrznej strony i konwencjonalnego przeszklenia

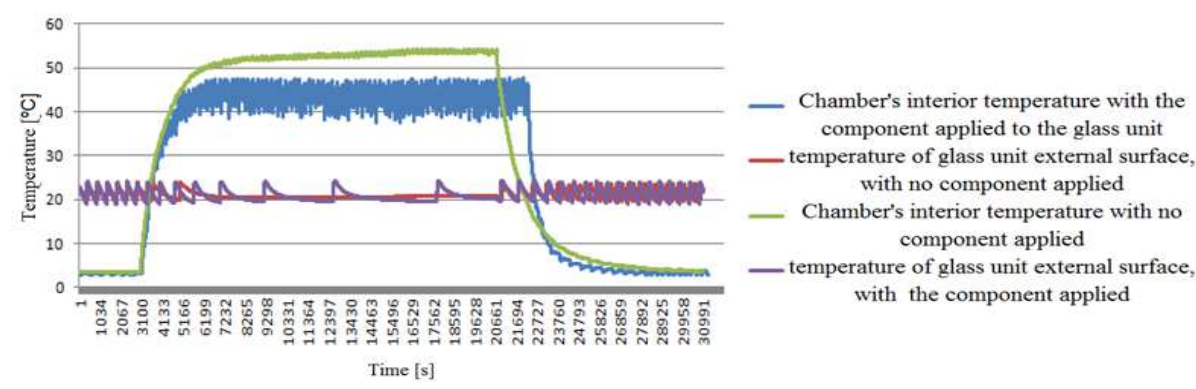

Fig. 10. Temperatures of the glazing and of internal air for unmodified glazing and externally modified glazing

Rys. 10. Wykres zestawiający temperatury przeszklenia i powietrza zewnątrz komory dla przeszklenia z PCM od wewnętrznej strony i konwencjonalnego przeszklenia

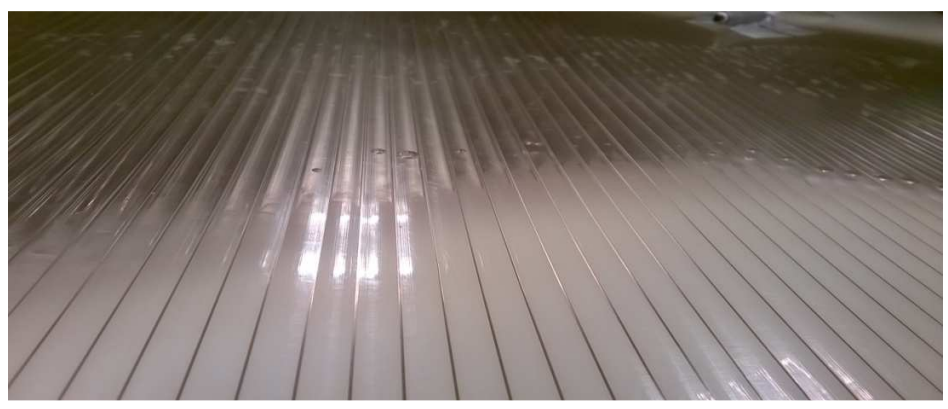

Fig. 11. A photography of PCM during phase transition

Rys. 11. Fotografia kompozytu podczas zmiany stanu skupienia materiału zmiennofazowego 


\section{Conclusions}

When a component was placed inside the chamber, certain reduction of heating energy consumption was observed, along with decrease of glass unit's external surface temperature, in comparison with unmodified solution.

As the component was placed on the external surface of the glass unit, heating energy consumption was higher than in two remaining cases.

It is to be explained with negative location of heat storage, i.e. the PCM.

Despite the fact, that significant portion of PCM had been melted, storing great amount of energy, most of it was transmitted outside the chamber due to considerable disproportion in thermal resistance of the glass unit, and component's external surface thermal resistance (R.se).

It leads to the conclusion, that mounting a PCM component outside the window is pointless in Polish temperate climate, however it may be sensible to do so in Mediterranean climate

In such a climate, the solution will decrease air conditioning energy consumption, while the translucent barrier will still provide some lighting to a building.

In both cases, application of PCM component reduced the magnitude of internal air temperature fluctuations, in comparison with unmodified glass unit, due to increased thermal inertia of modified solutions.

Application of PCMs to produce improved, translucent barriers may be sensible in compartments, that do not require transparent windows, such as toilets or dressing rooms.

It is to be noticed, that selection of physical properties of applied PCMs and the optimal thickness of it's layer would depend on barrier's orientation, and local climate conditions.

\section{Bibliography}

[1] Esam M., Alawadhi E. M.: Using phase change materials in window shutter to reduce the solar heat gain, Energy and Buildings, Volume 47, April 2012, Pages $421-429$.

[2] Grynning S., Goia F., Rognvik E., Time B.: Possibilities for characterization of a PCM window system using large scale measurements, International Journal of Sustainable Built Environment, Volume 2, Issue 1, June 2013, Pages 56-64.

[3] Hsino M., Pasławski J.: Materiały zmiennofazowe jako modyfikator betonu dojrzewającego w klimacie gorącym i suchym, www.izolacje.com \{dostęp 27.03.2015\}.

[4] Ismail K. A. R., Henriequez J. R.: PCM Glazing Systems, International Journal Of Energy Research, Vol. 21, 1997, Pages 1241-1255.

[5] Jaworski M.: Materiały zmiennofazowe (pcm) w budownictwie - właściwości i rodzaje, www.izolacje.com \{dostęp 27.03.2015\}.

[6] Shamberger P. J., Reid T.: Thermophysical Properties of Potassium Fluoride Tetrahydrate from (243 to 348) K, Jurnal of chemical \& engineering, Volume 58, 2013, Pages 294-300. 
[7] Silva T., Vicente R., Rodrigues F., Samagaio A., Cardoso C.: Development of a window shutter with phase change materials: Full scale outdoor experimental approach, Energy and Buildings, Volume 88, 1 February 2015, Pages 110-121.

[8] Soares N., Costa J. J., Gaspar A. R., Santos P.: Review of passive PCM latent heat thermal energy storage systems towards buildings energy efficiency, Energy and Buildings, Volume 59, April 2013, Pages 82-103.

\section{BADANIA WŁAŚCIWOŚCI PRZEGRÓD TRANSPARENTNYCH MODYFIKOWANYCH MATERIAŁAMI ZMIENNOFAZOWYMI POCHODZENIA ORGANICZNEGO}

\section{Streszczenie}

Obecnie, aby obniżyć koszty związane z utrzymaniem temperatury powietrza w budynku, coraz częściej wykorzystuje się odnawialne źródła energii. Jednym ze sposobów obniżenia kosztów utrzymania budynku jest ograniczenie strat ciepła oraz nadmiernego przegrzania pomieszczeń przez okna. W niniejszym artykule przedstawione zostały wstępne wyniki badań sprawdzających zasadność modyfikowania przeszkleń PCM-ami pochodzenia organicznego

W przeciągu kilku ostatnich lat można zaobserwować wzrost ilości prac naukowych opisujących możliwości modyfikowania materiałów budowlanych PCM-ami. Zdecydowana większość wyżej wspomnianych prac odnosi się do modyfikacji stropów, dachów i ścian wykonanych z różnych materiałów. Modyfikacja przeszkleń PCM-ami pozwala na zwiększenie bezwładności termicznej przegrody, zwiększenie oporu cieplnego szyby oraz utworzenie buforu cieplnego związanego z ciepłem przemiany fazowej PCM-u. Badaniom zostało poddane przeszklenie dwukomorowe o wymiarach $80,5 \mathrm{~cm}$ x $80,5 \mathrm{~cm}$, będące jedną ze ścian sześciennej komory. Wewnętrzna kubatura komory wynosi $1 \mathrm{~m}^{3}$. Materiałem zmiennofazowym użytym do badań jest mieszanina węglowodorów nasyconych i nienasyconych o temperaturze przemiany fazowej $38-41^{\circ} \mathrm{C}$ oraz cieple przemiany fazowej $135 \mathrm{~kJ} / \mathrm{kg}$. Opisaną wyżej komorę wraz z PCM-em poddano działaniu temperatury i promieniowania, odpowiadającym wartościom rzeczywistym w Polsce w sezonie zimowym. Dla zadanych warunków mierzono stopień [\%] zmiany fazy PCM-u, temperaturę przeszklenia oraz ilości energii potrzebnej do utrzymania stałej temperatury wewnątrz komory.

Wyniki zostały odczytane dla stałych warunków (temperatury i natężenia promieniowania) oraz różnych grubości PCM-u. Na podstawie przeprowadzonych badań określono ilość zużytej energii potrzebnej do utrzymania określonej temperatury w komorze. Dodatkowo określono grubość PCM-u, która pozwoli na jego racjonalne wykorzystanie. Przeprowadzone badania stanowią podstawę do prowadzenia dalszych modyfikacji cech chemicznych i fizycznych PCM-ów wykorzystywanych w budownictwie.

Słowa kluczowe: materiały zmiennofazowe, modyfikowane przegrody przezroczyste, ciepło utajone, izolacja termiczna

Przestano do redakcji: 24.09.2015 $r$.

Przyjęto do druku:1.03.2016 $r$.

DOI: $10.7862 / \mathrm{rb} .2016 .119$ 